\title{
Philodendron scandens Koch et Sello subsp. oxycardium (Schott) Bunting, A New Source of Allergenic Alkyl Resorcinols
}

\author{
TORSTEN REFFSTRUP, ${ }^{a}$ OLE HAMMERSH $Ø Y,{ }^{b}$ PER M. BOLL ${ }^{a, *}$ and HENNING SCHMIDT ${ }^{b}$
}

\author{
a Department of Chemistry, Odense University, DK-5230 Odense M, Denmark and ${ }^{b}$ Department of \\ Dermatology and Venerology, Odense University Hospital, DK-5000 Odense C, Denmark
}

The allergenic activity of Philodendron scandens Koch et Sello subsp. oxycardium (Schott) Bunting (Araceae) has been investigated. Patch testing on volunteers and chromatographic separation of extracts of the plant led after structural determination of the pure active component to proposal of $I$ as the allergenic constituent. A possible biosynthetic precursor (3) to 1 was isolated and identified. From the results of various extraction procedures the allergenic principles are believed to be associated with the cuticle.

Recently Philodendron scandens Koch et Sello subsp. oxycardium (Scott) Bunting (Araceae), indigenous to South America, but now widespread in the Western world, has been reported to cause allergenic contact dermatitis among gardeners working with the plant. ${ }^{1}$ As occupational allergic contact dermatitis is a problem of growing importance in the greenhouse industry $P$. scandens subsp. oxycardium was phytochemically examined in order to reveal the structures of the involved allergens.

\section{RESULTS}

In a pilot experiment fresh leaves and stems were exhaustively extracted with methanol and the extract was partioned between water and chloroform. Patch testing on volunteers occupationally sensitized towards the plant showed the allergenic activity to be exclusively associated with the chloroform extract. Gel filtration, recombination of fractions according to their TLC characteristics followed by patch testing allowed selection of an allergenic fraction which upon chromatography on silica gel afforded a partial separation into components

*To whom correspondence should be addressed.

allowing registration of some spectral information. Mass spectrometry and gas chromatography-mass spectrometry of the more olar constituents revealed a compound (1) showing two remarkably stable fragments at $m / e 123$ and 124 . These fragments had the elemental compositions $\mathrm{C}_{7} \mathrm{H}_{7} \mathrm{O}_{2}$ and $\mathrm{C}_{7} \mathrm{H}_{8} \mathrm{O}_{2}$, respectively, and were accompanied by a molecular ion at $m / e 342$ of elemental composition $\mathrm{C}_{23} \mathrm{H}_{34} \mathrm{O}_{2}$. Acetylation of crude 1 produced a diacetate; thus 1 is assumed to be a diol.

An accompanying compound 2 showed by GLCMS the somewhat similar characteristics of the two intense fragments at $\mathrm{m} / \mathrm{e} 107$ and 108 of elemental compositions $\mathrm{C}_{7} \mathrm{H}_{7} \mathrm{O}$ and $\mathrm{C}_{7} \mathrm{H}_{8} \mathrm{O}$, respectively, and a molecular ion of $m / e 326$ with the composition $\mathrm{C}_{23} \mathrm{H}_{34} \mathrm{O}$ was detected in another fraction of the partly separated fraction. In a "direct inlet" spectrum of 2 the peak at $m / e 326$ was still detectable, but additionally an ion at $m / e 370\left(\mathrm{C}_{24} \mathrm{H}_{34} \mathrm{O}_{3}\right)$ appeared. Apparently 2 could be an artifact obtained on the GLC-column on decarboxylation of a carboxylic acid, which then has to the genuine metabolite. To test this hypothesis the assumed carboxylic acid was esterified to give a methyl ester 4 . The IR spectrum of 4 indicated clearly the presence of an aromatic carboxylic ester. Since decarboxylation of aromatic carboxylic acids is highly facilitated by electron-donating ortho substituents 4 is assumed

The former data indicated also the type of compounds present since the very prominent peaks at

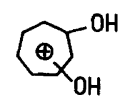

$a$

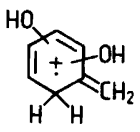

$b$

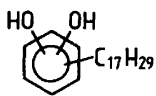

c 
$m / e 123$ and 124 are indicative of fragment of the types ${ }^{2} a$ and $b$ and since all the oxygen present in the molecule is associated with the aromatic ring, 1 is assigned the partial structure $c$, although the presence of more than one alkyl substituent cannot excluded.

To give more easily separable extracts a new batch of plant material was extracted differently. The coarsely cut stems and leaves of $P$. scandens were exhaustively extracted with light petroleum and chromatography on silica gel with gradient elution (ether in light peroleum gave the spectroscopically pure compounds 1 and 3 . The $270 \mathrm{MHz}$ ${ }^{1} \mathrm{H}$ NMR spectrum of 1 allowed assignment of all the signals in the aliphatic side chain on the basis of selective decoupling experiments. The configuration of the double bonds is considered all-cis since all the couplings of the vinylic signals are smaller than $10 \mathrm{~Hz}$. The assignments ( $c f$. Experimental) gave
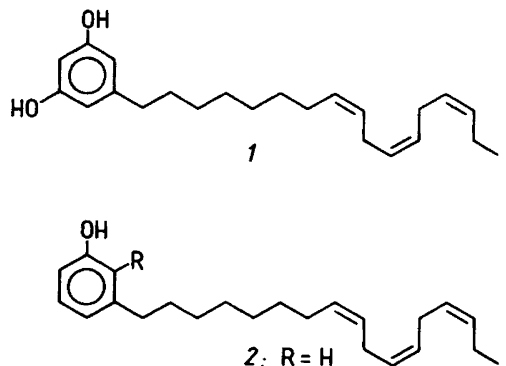

3: $\mathrm{R}=\mathrm{COOH}$

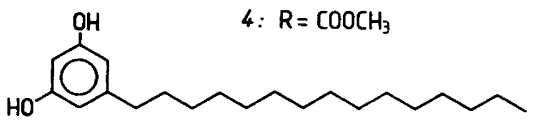

5

basis for constructing the side chain as given for 1. The spectrum showed additionally resonances corresponding to the aromatic protons of an alkyl substituted resorcinol with spin - spin couplings of about $2 \mathrm{~Hz}$. A computer simulation of the aromatic part of the spectrum confirmed this assignment.

The presence of the resorcinol group in 1 was further supported by. its UV spectrum which is similar to those quoted for the alkyl resorcinol grevillol $^{3}$ and a heptadecatetraenylresorcinol ${ }^{4}$ and also by the ${ }^{13} \mathrm{C}$ NMR spectrum which showed 4 resonances attributable to a symmetrically substituted aromatic system. The chemical shifts of these carbons and their multiplicity are also in accord with the proposed structure. Compound 1 is thus 5-heptadeca-8(Z),11(Z),14(Z)-trienylresorcinol.

The $270 \mathrm{MHz}{ }^{1} \mathrm{H}$ NMR spectrum of the carboxylic acid 3 showed three aromatic protons resonating at $\delta 7.21(1 \mathrm{H}, \mathrm{d}$ of t $)$ and $6.70(2 \mathrm{H}$, two dd). All protons show ortho couplings and the substitution pattern of the ring has to be $1,2,3$. It is further found that the chemical shifts of the $\alpha$-methylene group are shifted downfield by $0.45 \mathrm{ppm}$ in comparison with the value recorded for the corresponding protons in 1 . Therefore, the carboxyl group must be ortho to the alkenyl substituent. As the hydrogens para and ortho to a carboxyl group are deshielded, the proton resonating at $\delta 7.21$ is either ortho or para to the carboxyl group. Since this proton is a douplet of triplets, both with large ortho couplings, it has to be ortho to two protons and, therefore, para to the carboxyl group. The two highfield aromatic protons are thus assigned to be meta to the carboxyl group. The low field resonance of the phenolic proton of $4(\delta 10.9)$ is in agreement with this assignment and it also explains the ease of decarboxylation of 3. The spectral information thus gives evidence for a substitution pattern as given in 3 .

Apart from the deshielding of the protons of the $\alpha$-methylene group the pattern of the side chain of 3 is identical to that found for the resorcinol. Coupling patterns, number of protons and decoupling experiments give the conclusion that the side chains of 1 and 3 are identical. Compound 3 is thus 6-heptadeca- $8(Z), 11(Z), 14(Z)$-trienyl-2-hydroxybenzoic acid. The resorcinol (1) and the salicylic acid (3) would appear to be derived from a common $\mathrm{C}_{24}$ polyketide precursor.

The allergic activity of the total plant extracts can be completely destroyed upon treatment in ethanol for $24 \mathrm{~h}$ with traces of sodium hydroxide under stirred and aerated conditions. Patch testing on pure 1 as well as on the untreated total extract produced a vigorous response. Since phenols are known to be destroyed by oxygen and bases, the above experiment indicates that the allergic activity of $P$. scandens is mainly associated with 1 .

Among the various type of phenols, catechols ${ }^{5}$ and hydroquinones ${ }^{6}$ have frequently been found responsible for allergic reactions caused by plants. Since resorcinols only infrequently ${ }^{7}$ cause allergic contact dermatitis a fresh extract of $P$. scandens was investigated by GLC-MS for the presence of other phenols. The method applied to the trimethylsilylated extract revealed, in addition to 1 , trace amounts of a compound $\mathrm{C}_{21} \mathrm{H}_{32} \mathrm{O}_{2}$ believed to be 
pentadecylresorcinol (5); but no traces of catechols, detectable by their characteristic loss of $\mathrm{SiMe}_{4}{ }^{8}$ could be observed.

Application of the very sensitive electron paramagnetic (EPR) technique to a freshly prepared extract of the plant showed clearly that hydroquinones and catechols are not present. ${ }^{9}$ This information held together with the association of the main allergic activity with pure 1 gives support for our conclusion that 1 is the principal allergenic constituent of $P$. scandens.

\section{DISCUSSION}

The natural occurrence of 5-alkyl- and 5-alkenylresorcinols has been previously reported in the plant families Anacardiaceae (cashew nut shell oil), ${ }^{10,11}$ Ginkgoaceae (Ginkgo biloba), ${ }^{12}$ Gramineae, ${ }^{13}$ Proteaceae, ${ }^{14,15}$ and most recently, Myrcinaceae. ${ }^{16}$ Further, the isolation and characterization of two 5-alkylresorcinols from Azotobacter vinelandii ${ }^{17}$ and a 5-heptatetraenylresorcinol from the brown alga Cystophora torulosa ${ }^{4}$ have been reported.

6-Alkenylsalicylic acids have not been reported to cause allergic contact dermatitis, although they are reported to be antiinflammatory. ${ }^{18}$ Such compounds with a $\mathrm{C}_{15}$-side chain have been found in the cashew nut shell oil ${ }^{7}$ and in Ginkgo biloba. ${ }^{19}$ Salicylic acids with $\mathrm{C}_{17}$-side chains and various degrees of unsaturation have been detected from Pentaspodon officinalis and P. motlei. ${ }^{20}$

In view of the frequent occurrence of allergic contact dermatitis initiated by phenolic compounds, it is of interest to add new plant sources of allergenic phenols in order to predict and prevent cross reactions for persons already sensitized. The present paper shows Philodendron scandens subsp. oxycardium (Araceae) as a hitherto unrecognized source of long chain alkenylresorcinols and the compounds 1 and 3 are new with respect to structure and origin and they have been isolated and characterized. An investigation of nine other species of Philodendron has proved four more species to contain resorcinols. $^{21}$

It has also been found that the total amount of compounds 1 and 3 is extracted just by letting the coarsely cut stems and leaves stand in contact with light petroleum. Further extraction with more polar and water soluble solvents gave virtually no additional amounts of 1 and 3. This make us conclude that the allergenic principle is a constituent of the cuticle, which is very appropriate if the resorcinols are considered a defense weapon.

\section{EXPERIMENTAL}

Philodendron scandens subsp. oxycardium was grown in a nursery. Fresh leaves and stems were coarsely cut and extracted with methanol in a Soxleth extractor for the preliminary experiments. A more efficient extraction was effected by using the sequence: light petroleum, ethyl acetate and then methanol on fresh plant material. The light petroleum fraction was an extract mainly of the cuticle and almost all of the allergenic principle was present in this fraction. Separations were carried out by column chromatography on Sephadex LH20 in methanol and on Silica Woelm 62-100 with chloroform - ethyl acetate or ether-light petroleum by solvent gradient elution. In all cases fractions of each $10 \mathrm{ml}$ were collected.

TLC was performed on high performance silica coated plates (Merck). The plates were monitored by UV or by spraying with $1 \%$ vanillin in conc. $\mathrm{H}_{2} \mathrm{SO}_{4}$ and then heated. Mass spectra were recorded on a Varian Matt 311 or a Varian $\mathrm{CH} 7$ instrument both equipped with inlet for gas chromatography mass spectrometry. NMR spectra were obtained on Jeol Fx60 Q and Bruker Hx270 instruments. IR and UV spectra were recorded on Perkin Elmer 580 and Cary (Varian) 219 instruments, respectively.

5-Heptadecatri-8(Z),11(Z),14(Z)-enylresorcinol (1). The light petroleum extract (1.04 g) from $504 \mathrm{~g}$ of $P$. scandens was chromatographed on $200 \mathrm{~g}$ of silica gel with a gradient of ether in light petroleum and gave $25 \mathrm{mg}(0.005 \%)$ of 1 (10-ml fractions Nos. 146-156). UV (EtOH): $\lambda_{\max } 216 \mathrm{~nm}(\mathrm{sh}), 278 \mathrm{~nm}$ ( $\log \varepsilon$ 3.28); upon addition of $\mathrm{NaOH}$ the spectrum shifted to $\lambda_{\max } 236 \mathrm{~nm}$ and $290 \mathrm{~nm}(\log \varepsilon 3.21) .{ }^{1} \mathrm{H}$ NMR ( $\left.\mathrm{CD}_{3} \mathrm{OD}\right): \delta 0.96\left(3 \mathrm{H}, \mathrm{t}, J 8 \mathrm{~Hz}, \mathrm{CH}_{2} \mathrm{CH}_{3}\right)$, $1.30\left(8 \mathrm{H}, \mathrm{m},\left(\mathrm{CH}_{2}\right)_{4}\right), 1.54\left(2 \mathrm{H}, \mathrm{m}, \mathrm{ArCH}_{2} \mathrm{CH}_{2}\right)$, $2.05\left(4 \mathrm{H}, \mathrm{m}, \mathrm{CH}_{2} \mathrm{CH}=\right), 2.41\left(2 \mathrm{H}, \mathrm{t}, J 7 \mathrm{~Hz}, \mathrm{ArCH}_{2}\right)$, $2.75\left(4 \mathrm{H}, \mathrm{m},=\mathrm{CHCH}_{2} \mathrm{CH}=\right), 5.33(6 \mathrm{H}, \mathrm{m}, \mathrm{CH}=$ $\mathrm{CH}), 6.07(1 \mathrm{H}, \mathrm{dd}, J 2$ and $1.2 \mathrm{~Hz}, \mathrm{ArH}), 6.10(2 \mathrm{H}$, $\mathrm{d}, J 2 \mathrm{~Hz}, \mathrm{ArH}) \cdot{ }^{13} \mathrm{C}$ NMR $\left(\mathrm{CD}_{3} \mathrm{OD}\right): 156.7$ (s), 146.0 (s), 132.0, 130.4, 128.3, 127.7, 127.2, 108.0 (d), 100.1 (d), 35.8, 31.1, 29.7, 29.2, 27.3, 25.7, 20.6, 14.3. IR (film): $3380,3040,2930,1600 \mathrm{~cm}^{-1}$. MS: Found: $\mathrm{M}^{+}$342.2548. Calc. for $\mathrm{C}_{23} \mathrm{H}_{34} \mathrm{O}_{2}: 342.2558, \mathrm{~m} / \mathrm{e}$ (rel. int.) 342 (12), 177 (6), 163 (19), 149 (14), 137 (13), $136(8), 135(8), 125(8), 124$ (100), 123(47), 121 (7), $109(6), 108(10)$.

6-Heptadecatri-8(Z),11(Z),14(Z) - enyl-2-hydroxybenzoic acid (3). The above chromatographic procedure also furnished $81 \mathrm{mg}(0.016 \%)$ of pure 3 (10-ml fractions Nos. $40-57) .{ }^{1} \mathrm{H}$ NMR $\left(\mathrm{CD}_{3} \mathrm{OD}\right)$ :

Acta Chem. Scand. B 36 (1982) No. 5 
$\delta 0.95\left(3 \mathrm{H}, \mathrm{t}, \mathrm{J} 8 \mathrm{~Hz}, \mathrm{CH}_{2} \mathrm{CH}_{3}\right), 1.33\left(8 \mathrm{H}, \mathrm{m},\left(\mathrm{CH}_{2}\right)_{4}\right)$, $1.56\left(2 \mathrm{H}, \mathrm{m}, \mathrm{ArCH}_{2} \mathrm{CH}_{2}\right), 2.06\left(4 \mathrm{H}, \mathrm{m}, \mathrm{CH}_{2} \mathrm{CH}=\right)$, $2.79\left(2 \mathrm{H}, \mathrm{t}, J 6 \mathrm{~Hz}, \mathrm{ArCH}_{2}\right), 2.87(4 \mathrm{H}, \mathrm{m}$, $\left.=\mathrm{CHCH}_{2} \mathrm{CH}=\right), 5.32(6 \mathrm{H}, \mathrm{m}, \mathrm{CH}=\mathrm{CH}), 6.71$ ( $2 \mathrm{H}$, two dd, $J 7 \mathrm{~Hz}, \mathrm{ArH}), 7.22(2 \mathrm{H}, \mathrm{d}$ of $t, J 7$ and 1 $\mathrm{Hz}$ ) (the aromatic couplings have been calculated using the computational procedure). IR (film): 3600 to 2300 (broad), $3020,2940,1650,1600 \mathrm{~cm}^{-1}$. MS: Found: $\mathrm{M}^{+}$370.2481. Calc. for $\mathrm{C}_{24} \mathrm{H}_{34} \mathrm{O}_{3}: 370.2508$, $m / e$ (rel. int.) $371(9), 370(35), 175(6), 173(8), 164(5)$, 163 (7), 162 (9), 161 (14), 160 (6), 159 (8), 152 (18), 151 (22), 149 (14), $148(13), 147(27), 146(10), 145(6)$, $136(10), 135(20), 134(25), 133(19), 123(7), 122(14)$, $121(24), 120(10), 119$ (9), $109(21), 108(85), 107(51)$, $106(6), 105(27), 96(9), 95(78), 64(26), 93(45), 92(7)$, 91 (28), 83 (6), 82 (8), 81 (43), 80 (39), 79 (100), 78 (14), 77 (24), 69 (19).

Methyl 6-heptadecatri-8(Z),11(Z),14(Z)-2-hydroxybenzoate (4). Compound 3 (16 mg, 0.043 $\mathrm{mmol}$ ) was treated with diazomethane in ether for $5 \mathrm{~min}$. Upon evaporation 4 was obtained quantitatively. ${ }^{1} \mathrm{H}$ NMR $\left(\mathrm{CDCl}_{3}\right): \delta 3.95\left(3 \mathrm{H}, \mathrm{s}, \mathrm{CO}_{2} \mathrm{CH}_{3}\right)$, $11.09(1 \mathrm{H}, \mathrm{s}, \mathrm{OH})$. IR (film): $3450,3020,2970,1665$, $1610 \mathrm{~cm}^{-1}$. MS: $\mathrm{m} / \mathrm{e}$ (rel. int.) $385(10), 384(34)$, 283 (6), 201 (6), 187 (5), 173 (11), 166 (24), 165 (24), 163 (7), $162(8), 161(19), 160(7), 159(9), 149(14), 148$ (13), $147(30), 146(9), 145$ (7), $136(10), 135$ (26), 134 (24), 133 (19), 123 (6), 122 (14), 121 (27), 120 (10), $119(11), 109$ (18), $108(71), 107$ (46), $106(7), 105(24)$, $95(80), 94$ (23), 93 (46), 92 (6), 91 (27), 82 (6), 81 (39), 80 (33), 79 (100), 78(13), 77 (16).

Trimethylsilylation of extracts of $\mathbf{P}$. scandens. The light petroleum extract of leaves and stems corresponding to approximately $1 \mathrm{mg}$ of material was evaporated in a vial. Upon dissolution in hexane ( $2 \mathrm{ml}) 1$ drop of distilled pyridine and $0.01 \mathrm{ml}$ of $N, N$-bis(trimethylsilyl)acetamide were added. The vial was stoppered loosely and heated for $30 \mathrm{~min}$ at $60^{\circ} \mathrm{C}$. The reaction mixture was cooled and used directly for GC-Ms.

Acknowledgements. This paper is submitted in honour of Professor Holger Erdtman on the occasion of his 80th birthday in appreciation of his contributions to organic chemistry. We are indebted to Ms. Karsten F. Nielsen, Højrupvej 1, Hillerslev, DK-5750 Ringe for the plant material, to the Danish Natural Science and Medical Research Councils for a fellowship to T. Reffstrup and for use of their 270 MHz NMR spectrometer, and to Dr. J. A. Pedersen, University of Aarhus for performing the EPR experiments.

\section{REFERENCES}

1. Hammershøy, O. and Verdich, J. Contact Dermatitis 6 (1980) 95.
2. Budzikiewicz, H., Djerassi, C. and Williams, D. H. Mass Spectrometry of Organic Compounds, Holden-Day, San Francisco 1967.

3. Ritchie, E., Taylor, W. C. and Vautin, S. T. K. Aust. J. Chem. 18 (1965) 2015.

4. Gregson, R. P., Kazlauskas, R., Murphy, P. T. and Wells, R. J. Aust. J. Chem. 30 (1977) 2527.

5. Mitchell, J. and Rook, A. Botanical Dermatology, Greengrass, Vancouver 1979, p. 64 and references therein.

6. Mitchell, J. and Rook, A. Botanical Dermatology, Greengrass, Vancouver 1979, p. 68.

7. Mitchell, J. and Rook, A. Botanical Dermatology, Greengrass, Vancouver 1979, p. 67.

8. Harasimhachari, N. and Voros, P. Anal Biochem. 45 (1972) 154.

9. Pedersen, J. A. Personal communication; $c f$. Pedersen, J. A. Phytochem. 17 (1978) 775.

10. Backer, H. J. and Haack, N. J. Recl. Trav. Chim. Pays-Bas 60 (1941) 661.

11. Tyman, J. H. P. Chem. Commun. (1967) 982.

12. Furukawa, S. Sci. Pap. Inst. Phys. Chem. Res. Jpn. 26 (1935) 178.

13. Wenkert, W. E., Loeser, E. M., Mahapatra, S. N., Schenker, F. and Wilson, E. M. J. Org. Chem. 29 (1964) 435.

14. Cirigottis, K. A., Cleaver, L., Corrie, J. E. T., Grasby, R. G., Green, G. H., Mock, J., Nimigirawath, S., Read, R. W., Ritchie, R., Taylor, W. C., Vadasz, A. and Webb, W. R. G. Aust. J. Chem. 27 (1974) 345 and references therein.

15. Occolowitz, J. L. and Wright, A. S. Aust. J. Chem. 15 (1962) 858.

16. Madrigal, R. V., Spencer, G. F., Plattner, R. D. and Smith, C. R. Lipids 12 (1977) 402.

17. Reusch, R. and Sadoff, H. L. J. Bacteriol. 139 (1979) 448.

18. Kazlauskas, R., Mulder, J., Murphy, P. T. and Wells, R. J. Aust. J. Chem. 33 (1980) 1097.

19. Furakawa, S. Sci. Pap. Inst. Phys. Chem. Res. Jpn. 24 (1934) 304.

20. Lambertson, J. A. Aust. J. Chem. 12 (1959) 234.

21. Reffstrup, T. and Boll, P. M. Unpublished.

Received January 13, 1982. 